\title{
Rethinking Schizophrenia in the Light of new Euidence: Thirty Years after the Uermont Longitudinal Study of Persons with Severe Mental Illness
}

\author{
Alberto Fergusson*, Miguel Gutiérrez-Peláez ${ }^{* *}$
}

Despite new evidence, procedures, client testimony, and movements around the world, old myths regarding schizophrenia still prevail among both the public and mental health professionals. Thirty years have passed since the mind-blowing publication in 1987 of the Vermont Longitudinal Study of Persons with Severe Mental Illness (Harding, Brooks, Ashikaga, Straus, \& Breier), which led to Harding and Zahniser's 1994 article, Empirical Correction of Seven Myths about Schizophrenia with Implications for Treatment. Harding and Zahniser presented empirical evidence sufficient to dismantle seven common myths regarding schizophrenia:

1. Once a schizophrenic always a schizophrenic. Reality: Ever widening heterogeneity of outcomes across time;

2. A schizophrenic is a schizophrenic is a schizophrenic. Reality: Wide heterogeneity within the diagnostic category;

3. Rehabilitation can be provided only after stabilization. Reality: Rehabilitation should begin on day one;

4. Psychotherapy is pointless for schizophrenia. Reality: Supportive psychotherapy is crucial to integrating experience and enhancing continued adult development;
5. Patients must be on medication for the rest of their lives. Reality: Only a small percentage need permanent medication;

6. People with schizophrenia cannot perform any jobs except low-level ones. Reality: People with schizophrenia can and do perform well at every level of work;

7. Families are etiological agents. Reality: Families can provide critical information and provide environments to lower a relative's vulnerability to psychotic episodes (Harding \& Zahniser, 1994).

Other studies that followed provided additional evidence for these findings (DeSisto, Harding, McCormick, Ashikaga \& Brooks, 1995; Ascher-Svanum, Russo, Shumway \& Harding, 2003; Isaac, Chand \& Murthy, 2007; Cohen, Patel, Thara \& Gureje, 2008; Lieberman, Drake, Sederer, Belger, Keefe, Perkins \& Stroup, 2008; Jääskeläinen, Juola, Hirvonen, McGrath, Saha, Isohanni, et al., 2013).

Despite these findings, we continue to hear the same myths and prejudices expressed by practitioners, health professionals, families, and people diagnosed with schizophrenia. We must once more review all available studies and empirical evidence

\footnotetext{
* Universidad del Rosario, Director of the Center for Psychosocial Studies (CEPSO/CEPSS), School of Medicine and Health Sciences. Vice-president of the World Association for Psychosocial Rehabilitation (WAPR). E-mail: afergusson@selfrehabilitation.org

** Universidad del Rosario, Director of the Psychology Program, School of Medicine and Health Sciences. People, Family, and Society Research Group, Bogotá, Colombia. E-mail: miguel.gutierrez@urosario.edu.co
} 
in order to rethink schizophrenia, to take a close look at what we know and what we don't know, and review the impact of this distinction on the treatments we offer and those that we could offer.

Throughout the past century and this one, many scientific, social, and political movements have presented a variety of alternatives for the treatment of psychosis. These movements have included the anti-psychiatric movement and the influential works of Franco Basaglia (1976); Basaglia, Scheper-Hughes, Lovell \& Shtob (1987); Basaglia \& Basaglia Ontaro (1975; 1981 \& 2005), David Cooper (1967; 1968; 1971), Maxwell Jones (1952; 1962; 1968; 1976; 1979a; 1979b; 1980; 1982; \& 1984), Ronald Laing (1960; 1967; 1976, \& 1985); Laing \& Esterson (1964), and Thomas Zsasz (1976; 1977; 1986; 2001 \& 2002), as well as Accompanied Autoanalysis (self-rehabilitation or self-recovery) in Colombia and the United States (Fergusson, 2014).

The voices of persons with psychotic illness and functioning had been silenced and discredited for centuries, but some began to listen to them at the beginning of the twentieth century. Psychiatrists such as Lombroso (2009), Prinzhorn (1922/2012), and Morgenthaler (1921/1985) began to identify theretofore unrecognized talent among their most disturbed patients. In subsequent instances, people suffering from mental illness described their own mental functioning and their experiences with psychiatric and psychological treatments. Two examples were Schreber's Memoirs (1955) and Clifford Beers' paradigm-breaking autobiography (1922). It was out of Schreber's autobiographical book that Freud (1911) derived his theory that delusions are a way of seeking recovery, an intent to cure that is coherent with the psychoanalytic goal of unveiling the subject hidden behind his or her symptoms. From 1980 on, biographies of people with autism have contested the rigid and naïve conceptions of their mental functioning (Gutiérrez-Peláez 2014; Maleval 2011 \& 2012). Outstanding examples of this valuable literature include the works of
Grandin (2006), Higashida (2013), Sellin (1994), Tammet (2006), and Williams (1994 \& 1999).

Despite evidence of its efficacy for recovery (Gutiérrez-Peláez \& Villamil-Díaz, 2015), psychotherapy is prescribed only occasionally and medication is still the number one treatment for most cases of psychosis. Despite new evidence, treatments for schizophrenia have not been broadly changed for decades. New forms of treatment have been introduced and evidence of their effectiveness and efficacy have been presented, but they continue to be applied only marginally. In Colombia, for example, Fergusson has treated homeless people diagnosed with psychosis for over thirty years through the method of accompanied selfrehabilitation or self-analysis, a method that he created and systematized (Diaz, Fergusson \& Strauss 2004; Gutiérrez 2013; Fergusson 2014; Gutiérrez-Peláez 2015; Harding 2015). At his institute for accompanied self-rehabilitation, $77 \%$ of participants have been treated without medication. This method has recently been replicated in Washington D.C. and Vermont in the United States, and in Scandinavian countries, where practitioners have developed the Open Dialogue model (Seikkula \& Arnkil, 2014).

In other countries such as France and Belgium, institutions like Le Courtil and Antenne 110 offer treatments based on Lacanian psychoanalysis, and their interventions for mentally disturbed children have been shown to be effective (Coccoz, 2014). Other programs have successfully introduced and implemented peer support groups for psychosis, which have proven to be beneficial in certain cases (Castelein, Bruggeman, van Busschbach, van der Gaag, Stant, Knegtering, \& Wiersma, 2008).

Several movements around the globe take different approaches and have different ways of understanding psychosis. They include the Hearing Voices Network, Mind Freedom (directed by David Oaks), the International Center for the Study of Psychiatry and Psychology (ICSPP), and the International Society for Ethical Psychology and Psychiatry (ISEPP), among others. The recovery model in the 
US is stronger every day and voices such as that of psychologist Pat Deegan, formerly diagnosed with severe mental illness, are trending in both mental health and medical attention in general. Many of these groups have strongly criticized the use of the term schizophrenia, which has appeared in the literature for more than a century since Bleuler introduced it in 1907. The International Society for the Psychological Treatments of Psychosis (ISPS), for example, has criticized the term, arguing that the concept itself has no real scientific foundation, while it does have great power to stigmatize people so diagnosed. This criticism has been echoed by detractors from diverse sectors, including radical voices that object to pharmaceutical practices and treatments, such as Peter Breggin and Peter C. Gotzsche, or Allen Frances and others who have strongly opposed the approach of the DSM-V. There is also a growing concern regarding the early mortality rates in people with schizophrenia (Laursen, Nordentoft \& Mortensen, 2014).

\section{A Word on Mental Health in Post-Conflict Colombia}

Colombia has been struggling since 2012 to reach a peace agreement between guerrilla groups and the government. This led to a cease fire and demobilization of guerrillas in 2016, after more than fifty years of active warfare with the Revolutionary Armed Forces of Colombia (FARC), and to the beginning of peace negotiations with the National Liberation Army (ELN) in February 2017. We do not yet know with certainty how the FARC or ELN guerrillas have dealt with cases of psychosis or schizophrenia. The possible effects of the guerrilla lifestyle on the nature of their symptoms is still no more than speculation, and we do not yet know whether or not they have received proper treatment. The truth is that as peace agreements are implemented, a significant proportion of the population that used to be treated informally will now have access to government health services.
There is a need for professionals trained especially for the treatment of this population, specialists who can overcome their prejudices against both ex-combatants and people suffering from psychosis (Letovancová, Kovalčíková, \& Dobríková, 2017; Magliano, Strino, Punzo, Acone, Affuso, \& Read, 2017; Verhaeghe, Bracke, \& Bruynooghe; 2008; Slobodin \& De Jong, 2015). Academic research plays a key role in this matter. Researchers conducting epidemiological studies should be alerted of the possible false unification of research samples (Gutiérrez-Peláez, 2017), not letting these overshadow the value of testimony by subjects who experience or have experienced the effects and consequences of psychosis, of well documented clinical cases, and the voices of different movements and thinkers who have gradually been increasing their visibility.

Psychiatry has always been interested in finding the physical substrate of mental disorders ranging from theses of organicity, brain dysfunction, neurotransmitter imbalances, and genetic predispositions, extending even to environmental and dietary hypotheses. Psychological hypotheses do not serve as grounded evidence, however, and the work of Szasz (2011) remains relevant in facing this dilemma. As clinicians and researchers, we celebrate any thorough advances on the etiology of schizophrenia, but we believe that even if science proves a physical cause for a homogeneous entity called schizophrenia, and if it is indeed "a heritable psychiatric disorder" (Sekar, Bialas, Rivera, Davis, Hammond, Kamitaki, et al., 2016), there is still a person behind the diagnosis who needs to process the consequences of the disease and the most singular way in which it affects his personal and social life. It is that subject whom we must assist and offer the best possible treatment for recovery.

We need to systematically review what we know and what we do not know in the light of new evidence. We need to find ways to communicate the knowledge derived from academic research on schizophrenia and psychosis to professionals 
working with this population, and to people with schizophrenia and their families. Thus can we begin to break down the rock-solid prejudices that have been rooted in humanity for centuries.

\section{References}

Ascher-Svanum, H., Russo, P., Shumway, M., \& Harding, C. (2003). The schizophrenia care and assessment program (SCAP): A large longitudinal observational study of schizophrenia in the US. Biological Psychiatry, 53(8), 99S-99S.

Basaglia, F. (1979) Brazilian Conferences. Milan: Raffaello Cortina.

Basaglia, F., Scheper-Hughes, N., Lovell, A. M., \& Shtob, T. (1987) Psychiatry Inside Out: Selected Writings of Franco Basaglia. New York: Columbia University Press.

Basaglia, F., \& Basaglia, O. F. (1975). Crimini di Pace: Ricerche sugli Intellettuali e sui Tecnici come Addetti all'Oppressione. Torino: G. Einaudi.

Basaglia, F., \& Basaglia, O. F. (1981) Scritti (2 vols.) Torino: Einaudi.

Basaglia, F., \& Basaglia, O. F. (2005) L'Utopia della Realta. Torino: Giulio Einaudi.

Beers, C. W. (1921). A Mind That Found Itself. Pittsburg, USA: University of Pittsburgh Press.

Castelein, S., Bruggeman, R., van Busschbach, J. T., van der Gaag, M., Stant, A. D., Knegtering, H., \& Wiersma, D. (2008). The effectiveness of peer support groups in psychosis: a randomized controlled trial. Acta psychiatrica Scandinavica, 118(1), 64-72.

Cohen, A., Patel, V., Thara, R., Gureje, O. (2008). Questioning an axiom: better prognosis for schizophrenia in the developing world? Schizophrenia Bulletin 34(2), 229-44.

Coccoz, V. (comp.) (2014). La práctica lacaniana en instituciones I. Buenos Aires: Argentina: Grama.

Cooper, D. (1967). Psychiatry and Anti-Psychiatry. London: Tavistock Publications.
Cooper, D. (1968). Beyond words. In: Cooper D (Ed.). The Dialectics of Liberation. Harmondsworth, UK: Penguin Books, 193-202.

Cooper, D. (1971). The Death of the Family. London: Allen Lane.

DeSisto, M., Harding, C. M., McCormick, R. V., Ashikaga, T., \& Brooks, G.W. (1995). The Maine and Vermont Three-Decade Studies of Serious Mental Illness. I. Matched Comparison of Cross-Sectional Outcome, and II. Longitudinal Course Comparisons. British Journal of Psychiatry, 167, 338-342.

Diaz, E., Fergusson, A., \& Strauss, J. (2004). Innovative Care for the Homeless Mentally Ill In Colombia. In Jenkins JH, Barret RJ, (eds.) Schizophrenia, Culture and Subjectivity. The Edge of Experience (pp. 219-237). Cambridge: Cambridge University Press.Fergusson, A. (2014). Accompanied Self-Rehabilitation. Bogotá, Colombia: Universidad del Rosario.

Freud, S. (1911). Psycho-Analytic Notes On An Autobiographical Account Of A Case Of Paranoia (Dementia Paranoides) (Ed. y Trad.) The standard edition of the complete psychological works of Sigmund Freud. (Vol. XII (1911-1913): The Case of Schreber, Papers on Technique and Other Works, 1961, pp. 341). London: Hogarth Press.

Grandin, T. (2006). Thinking In Pictures. My Life with Autism. New York, USA: Vintage Press.

Gutiérrez, R. (2013). Alberto Fergusson. Instituto de Auto-rehabilitación Acompañada. Colombianos que cambian el mundo. Planeta: Bogotá.

Gutiérrez-Peláez, M. (2014). El psicoanálisis de orientación lacaniana en el tratamiento del autismo. Affectio Societatis, 11(21), 1-8.

Gutiérrez-Pelaez, M. (2015). Prólogo. In Fergusson, A. (autor) Cartas imaginarias a Freud y otros ensayos (pp. ix-xii), Bogotá, Colombia: Universidad del Rosario.

Gutiérrez-Peláez, M., \& Villamil-Díaz, J. (2015). La psicoterapia de orientación psicodinámica en el tratamiento integral de pacientes con esquizofre- 
nia y sus familias. Clínica Contemporánea, 6(2), 69-83. doi: http://dx.doi.org/10.5093/cc2015a7 Gutiérrez-Peláez, M. (2017). Retos para las intervenciones psicológicas y psicosociales en Colombia en el marco de la implementación de los acuerdos de paz entre el gobierno y las FARCEP. Avances en Psicología Latinoamericana, 35(1), 1-8.

Harding, C. M., Brooks, G. W., Ashikaga, T., Strauss, J. S., \& Brier, A. (1987). The Vermont Longitudinal Study of Persons with Severe Mental Illness, I: Methodology, Study Sample, and Overall Status 32 Years Later. American Journal of Psychiatry, 144(6), 718-726.

Harding, C. M., \& Zahniser, J. H. (1994). Empirical Correction of Seven Myths about Schizophrenia with Implications for Treatment. Acta Psychiatrica Scandinavica, 90 (Suppl. 384), 140-146.

Harding, C. M. (2015). Foreword. In Fergusson, A. (author) Accompanied Self-Rehabilitation (pp. IX-X). Bogotá, Colombia: Universidad del Rosario.

Higashida, N. (2013). The Reason I Jump. The Inner Voice of a Thirteen-Year-Old Boy with Autism. New York: Random House.Isaac, M., Chand, P., Murthy, P. (2007). Schizophrenia outcome measures in the wider international community. The British Journal of Psychiatry 191(50), s71-s77.

Jääskeläinen, E., Juola, P., Hirvonen, N., McGrath, J.J., Saha, S., Isohanni, M., Veijola J., Miettunen, J. A. (2013). A systematic review and meta-analysis of recovery in schizophrenia. Schizophrenia Bulletin, 39, 1296-306.

Jones, M. (1952). Social Psychiatry: A Study of Therapeutic Communities. London: Tavistock $\mathrm{Pu}-$ blications.

Jones, M. (1962). Social Psychiatry in the Community, in Hospitals, and in Prisons. Springfield, IL: Charles C. Thomas.

Jones, M. (1968). Beyond the Therapeutic Community: Social Learning and Social Psychiatry. New Haven, CT: Yale University Press.
Jones, M. (1976). Why open systems? A personal account. In R. Hirschowitz \& B. Levy (ed.) The Changing Mental Health Scene (pp. 369-378). New York: Spectrum Publications.

Jones, M. (1979a). Therapeutic communities, old and new. American Journal of Drug and Alcohol Abuse, 6, 137-149.

Jones, M. (1979b). The therapeutic community, social learning and social change. In.D. Hinshelwood \& N. Manning (eds.), Therapeutic Communities, Reflections and Progress (pp. 1-9). London: Routledge \& Kegan Paul.

Jones, M. (1980). Desirable features of a therapeutic community in prison. In H. Toch (ed.) Therapeutic Communities in Corrections (pp. 34-40). New York: Praeger.

Jones, M. (1982). The Process of Change. Boston, MA: Routlegde \& Kegan Paul.

Jones, M. (1984). Why two therapeutic communities? Journal of Psychoactive Drugs, 16, 23-26.

Laing, R. D. (1960). The Divided Self: An Existential Study in Sanity and Madness. London: Tavistock.

Laing, R. D. (1967). The Politics of Experience and the Bird of Paradise. Harmondsworth, UK: Penguin.

Laing, R. D. (1976). The Facts of Life: An essay in feelings, facts, and fantasy. New York: Pantheon.

Laing, R. D. (1985). Wisdom, Madness and Folly: The making of a psychiatrist. New York: McGraw-Hill.

Laing, R. D., \& Esterson, A. (1964). Sanity, Madness, and the Family: Vol. I. Families of schizophrenics. London: Tavistock.Laursen, T.M., Nordentoft, M., Mortensen, P.B. (2014). Excess early mortality in schizophrenia. Annual Review of Clinical Psychology, 10, 425-48.

Letovancová, K., Kovalčíková, N., \& Dobríková, P. (2017). Attitude of Society towards People with Mental Illness: The Result of National Survey of the Slovak Population. International Journal of Social Psychiatry, 1-6, doi: 10.1177/0020764017696334 
Lombroso, C. (2009). Arte, genio y locura. Minerva: Revista del Círculo de Bellas Artes, 11, 80-83. Magliano, L., Strino, A., Punzo, R., Acone, R., Affuso, G., \& Read, J. (2017). Effects of the Diagnostic Label 'Schizophrenia', Actively Used or Passively Accepted, on General Practitioners' Views of this Disorder. International Journal of Social Psychiatry, 1-11. doi: 10.1177/0020764017695353

Maleval, J.-C. (2011). El autista y su voz, Madrid. España: Gredos.

Maleval, J. C. (2012). ¡Escuchen a los autistas! Grama: Madrid.

Morgenthaler, W. (1992). Madness and Art, the Life and Works of Adolf Wölfli. London: University of Nebraska Press. (Original work published in 1921).

Prinzhorn, H. (1972). Artistry of the Mentally Ill: A Contribution to the Psychology and Psychopathology of Configuration (2. ${ }^{\text {a }}$ ed.). New York: Springer- Verlag. (Original work published in 1922).

Seikkula, J., \& Arnkil, E. (2014). Open Dialogues and Anticipations. Respecting Otherness in the Present Moment. Finland: Teema.

Sekar, A., Bialas, A. R., Rivera, H., Davis, A., Hammond, T. R., Kamitaki, N., ...Tooley, K. (2016). Schizophrenia risk from complex variation of complement component 4. Nature, 530, 177183. doi: 10.1038/nature 16549

Sellin, B. (1994). Quiero dejar de ser un dentrodemi. Mensajes desde una cárcel autista. Barcelona, España: Galaxia Gutemberg/Círculo de lectores.

Schreber, D. P. (1955). Memoirs of My Nervous Illness. New York, USA: New York Review of Books.

Slobodin, O., \& De Jong, J. T. (2015). Mental Health Interventions For Traumatized Asylum Seekers
And Refugees: What Do We Know About Their Efficacy? International Journal of Social Psychiatry 61(1), 17-26.

Szasz, T. S. (1976). Schizophrenia: The Sacred Symbol of Psychiatry. Syracuse, NY: Syracuse University Press: 1988.

Szasz, T. S. (1977). Psychiatric Slavery: When Confinement and Coercion Masquerade as Cure. Syracuse, NY: Syracuse University Press.

Szasz, T. S. (1982). The Psychiatric Will: A new mechanism for protecting persons against "psychosis" and psychiatry. American Psychology, 37, 762-770.

Szasz, T. S. (2001). Pharmacracy: Medicine and Politics in America. Syracuse, NY: Syracuse University Press.

Szasz, T. S. (2002). Liberation by Oppression: A Comparative Study of Slavery and Psychiatry. New Brunswick, NJ: Transaction.

Szasz, T. S. (2011). The Myth of Mental Illness: Foundations of a Theory of Personal Conduct. New York, USA: Harper Collins.

Tammet, D. (2006). Nacido en un día azul. Un viaje por el interior de la mente y la vida de un genio autista, Barcelona, España: Sirio.

Verhaeghe, M., Bracke, P., \& Bruynooghe, K. (2008). Stigmatization and Self-Esteem of Persons in Recovery from Mental Illness: The Role of Peer Support. International Journal of Social Psychiatry, 54(3): 206-218. doi: 10.1177/0020764008090422

Williams, D. (1994). Somebody Somewhere. Breaking Free From the World of Autism. New York, USA: Tree Rivers Press.

Williams, D. (1999). Nobody Nowhere. The Remarkable Autobiography of an Autistic Girl. London, England: Jessica Kingsley Publishers. 